\title{
Peningkatan pengetahuan guru dan orang tua siswa taman kanak- kanak tentang penggunaan suplemen vitamin yang tepat
}

\author{
Binar Asrining Dhiani ${ }^{1 \star}$, Siti Nurjanah ${ }^{2}$, Narendra Istia Putri ${ }^{3}$, Ihza \\ Ihtimamul Umam ${ }^{4}$
}

${ }^{1}$ Universitas Muhammadiyah Purwokerto, Indonesia, email: binar_dhiani@ump.ac.id

${ }^{2}$ Universitas Muhammadiyah Purwokerto, Indonesia, email: janah_pwt@gmail.com

${ }^{3}$ Universitas Muhammadiyah Purwokerto, Indonesia, email: narendraistiap@gmail.com

${ }^{4}$ Universitas Muhammadiyah Purwokerto, Indonesia, email: ihzaiu@gmail.com

*Koresponden penulis

\section{Info Artikel}

Diajukan: 18 Nov 2020

Diterima: 28 Mar 2021

Diterbitkan: 15 Apr 2021

Keywords:

vitamin supplement; drug; appropriate drug usage

Kata Kunci:

suplemen vitamin; obat; penggunaan obat yang tepat

\section{Lisensi:}

cc-by-sa

\begin{abstract}
COVID-19 global pandemic increases the usage of vitamin supplement products. However, easy access to purchase and consume the product increases the risk for its misuse. Lack of information and or misinformation available for vitamin supplement product usage leads to its abuse. Teachers' and parents' role in deciding the choice and use of vitamin supplement products for the pupil and children is crucial. Thus, a program was held to provide information about the correct usage of vitamin supplement products for teachers and parents. The program was performed for the teachers and pupil parents of TK Aisyiyah Ledug via online. The attractive audio-visual program materials were delivered via animation video, artistic leaflet, and presentation. The teachers and parents responded positively toward the program. All attendants actively participated, and $100 \%$ of attendants agreed that the program was interesting and increased their knowledge on the appropriate usage of vitamin supplement products.
\end{abstract}


kegiatan juga didapatkan dari peserta. Hal ini diketahui dari tingkat partisipasi seluruh peserta dalam diskusi dan hasil angket evaluasi pelaksanaan kegiatan dimana $100 \%$ peserta menyatakan kegiatan ini mudah dipahami, menarik dan menambah pengetahuan tentang penggunaan vitamin yang tepat.

\section{PENDAHULUAN}

Vitamin adalah senyawa organik yang dibutuhkan dalam jumlah sedikit namun berperan penting dalam berbagai proses biokimiawi (Zhang et al., 2020). Secara umum vitamin tidak dapat dihasilkan oleh tubuh sendiri sehingga harus diperoleh dari asupan dari luar (Zhang et al., 2020). Terdapat dua golongan vitamin yang bermanfaat untuk tubuh, yaitu vitamin yang larut lemak (vitamin A, D, E, dan K) dan vitamin yang larut dalam air (vitamin B dan C). Semua jenis vitamin tersebut dapat dengan mudah ditemukan pada hidangan yang biasa dikonsumsi sehari-hari. Oleh karena itu, kebutuhan vitamin sebenarnya dapat terpenuhi dari makanan lengkap yang dikonsumsi sehari-hari.

Ketidaklengkapan unsur makanan dalam pola diet menyebabkan tubuh kekurangan asupan vitamin tertentu. Kekurangan asupan vitamin akan menyebabkan seseorang mengalami gangguan penyakit. Gangguan penyakit tersebut antara lain beri-beri, skorbut, depresi, anemia megaloblastik, dan lain-lain tergantung jenis vitaminnya (Kamangar \& Emadi, 2012; Triana, 2006). Kondisi kekurangan vitamin akibat asupan makanan yang tidak lengkap harus diatasi dengan konsumsi produk suplemen vitamin.

Namun, konsumsi suplemen vitamin secara berlebihan juga akan meningkatkan resiko terjadinya penyakit. Penyakit yang disebabkan akibat kelebihan vitamin misalnya kerusakan ginjal, gangguan penglihatan, kanker prostat dan bahkan kematian (Kamangar \& Emadi, 2012). Bila seseorang mengalami kelebihan jenis vitamin yang larut air seperti vitamin B dan C, maka kerja ginjal akan terganggu akibat dipaksa untuk mengeksresikan senyawa dalam jumlah tinggi. Adapun konsumsi vitamin larut lemak berlebihan seperti vitamin A, D, E dan K, akan menyebabkan deposit senyawa dalam jaringan seperti otak, tulang, dan hati. Deposit vitamin yang berlebihan pada jaringan tersebut dapat menyebabkan gangguan saraf, gangguan hati dan tekanan darah tinggi (Kamangar \& Emadi, 2012). Sehingga, penggunaan suplemen vitamin pun harus dilakukan dengan tepat sesuai aturan penggunaannya baik takaran jumlah (dosis) maupun durasinya.

Pasar suplemen vitamin di Indonesia yang semakin meningkat di tahun 2018 hingga mencapai Rp. 20,74 triliun (Fauziah, 2018) mendorong iklan produk suplemen vitamin beredar luas di masyarakat. Iklan menjadi salah satu sumber informasi mengenai penggunaan suplemen vitamin, yang sering kali kurang lengkap dan mengandung informasi yang kurang tepat (Herriman et al., 2017).

Situasi wabah pandemi global COVID-19 menyebabkan masyarakat semakin memburu suplemen vitamin untuk menangkal virus penyebab COVID-19 (Jovic et al., 2020). Meningkatnya kesadaran kelompok masyarakat tertentu untuk menjaga kesehatan termasuk ibu hamil, atlet, dan 
anak-anak menjadikan hampir 90\% kelompok masyarakat ini mengkonsumsi suplemen vitamin (Amanah et al., 2019; Amani, 2019; Madjri et al., 2011). Kekhawatiran yang muncul berlebihan akibat situasi wabah COVID-19 serta kemudahan akses untuk mendapatkan produk suplemen vitamin (Herriman et al., 2017) meningkatkan kemungkinan penyalahgunaan suplemen vitamin oleh konsumen terbesarnya, yaitu orangtua dan anak-anaknya.

Peran guru dan orangtua terhadap peserta didik dan anggota keluarganya sangat penting karena dapat mempengaruhi pengambilan keputusan terhadap pemilihan konsumsi suplemen vitamin (Evans et al., 2012; Herriman et al., 2017; Piekara et al., 2020). Oleh karena itu, diperlukan peningkatan pengetahuan bagi guru dan orangtua siswa dalam penggunaan suplemen vitamin yang aman dan benar.

Guru dan orangtua siswa TK Aisyiyah Ledug memiliki latar belakang ekonomi dan status sosial menengah ke bawah. Hampir semua guru dan orangtua siswa tidak memiliki akses informasi yang memadai tentang penggunaan suplemen vitamin yang tepat. Oleh karena itu, pemberian informasi mengenai penggunaan suplemen vitamin melalui berbagai alat peraga yang menarik dan mudah dipahami sangat diperlukan untuk mengatasi permasalahan tersebut. Dengan demikian, pemberian informasi diharapkan dapat meningkatkan pengetahuan guru dan orangtua siswa tentang penggunaan suplemen vitamin. Meningkatnya pengetahuan guru dan orangtua siswa TK Aisyiyah Ledug akan bermanfaat pada ketepatan pemilihan dan penggunaan suplemen vitamin oleh guru dan orangtua siswa untuk peserta didik dan anggota keluarganya.

Berdasarkan analisa tersebut di atas maka suatu kegiatan pemberian informasi/pengetahuan bagi guru dan orangtua siswa TK Aisyiyah Ledug Kecamatan Kembaran Kabupaten Banyumas tentang penggunaan suplemen vitamin yang aman dan benar telah dilaksanakan.

\section{METODE PELAKSANAAN}

Kegiatan ini dilaksanakan pada hari Sabtu dan Minggu di bulan Juli tahun 2020. Peserta terdiri dari guru dan orangtua/wali siswa TK Aisyiyah Ledug yang tergabung dalam grup WhatsApp Walmur TK ABA Ledug 20/21. Pada hari pertama kegiatan diikuti oleh sebanyak 29 dan berkurang menjadi 20 peserta pada hari kedua.

Metode penyampaian materi disampaikan secara daring dengan memanfaatkan platform WhatsApp. Kegiatan dilakukan melalui pemaparan materi menggunakan media audio visual berupa video animasi berjudul "Jangan Minum Vitamin Sembarangan", leaflet, dan materi presentasi yang menarik. Video animasi berisi mengenai informasi mengenai "do's and don't" penggunaan suplemen vitamin. Sumber utama leaflet dan materi presentasi berasal dari buku saku "Suplemen Kesehatan untuk Memelihata Daya Tahan Tubuh dalam Menghadapi COVID-19" yang diterbitkan oleh Badan Pengawasan Obat dan Makanan Republik Indonesia.

Tahapan kegiatan pada hari pertama dilaksanakan dalam bentuk penyampaian materi yang didahului dengan pre-test. Pre-test dilakukan 
dengan mengisi form yang dibuat menggunakan Google Form. Pre-test berupa lima buah pertanyaan dasar yang bertujuan untuk mengetahui tingkat pengetahuan awal peserta mengenai vitamin dan penggunaannya secara tepat. Bersamaan dengan pre-test, peserta diminta untuk mengisi form identitas diri untuk mendapatkan informasi karakteristik populasi peserta.

Kegiatan hari kedua dilanjutkan dengan diskusi dan tanya jawab mengenai materi penggunaan vitamin yang tepat dan post-test. Post-test dilakukan menggunakan Google Form berupa lima buah pertanyaan yang sama dengan pertanyaan pada saat pre-test. Post-test dilakukan untuk mengetahui tingkat pengetahuan peserta tentang penggunaan vitamin yang tepat setelah mengikuti pemaparan materi dan diskusi.

Evaluasi pelaksanaan program dan keberlanjutan program dilakukan menggunakan kuesioner yang wajib diisi oleh peserta setelah dilaksanakan post-test. Evaluasi pelaksanaan program dilakukan untuk mengetahui efektifitas penyampaian dan ketepatan metode yang digunakan dalam penyampaian materi.

\section{HASIL DAN PEMBAHASAN}

\section{Karakteristik Peserta dan Perilaku Penggunaan Suplemen Vitamin}

Karakteristik guru dan orangtua siswa di TK Aisyiyah peserta kegiatan ini sebagian besar berusia 31 hingga 40 tahun yang terbiasa dengan penggunaan sosial media. Peserta memiliki latar belakang pendidikan beragam, yaitu dari SMP hingga sarjana dengan jumlah terbesar berpendidikan sarjana. Status ekonomi peserta merupakan kelompok ekonomi menengah kebawah menurut definisi kelompok menengah versi Asian Development Bank (ADB) (Nizar, 2015) (Tabel 1.).

Tabel 1. Persentase status usia, pendidikan terakhir dan total pendapatan keluarga dari peserta

\begin{tabular}{ccc} 
& kegiatan & \\
\hline Karakteristik & Jumlah & $\%$ \\
\hline Usia (tahun) & & \\
$20-25$ & 0 & 0 \\
$26-30$ & 4 & 13,8 \\
$31-35$ & 9 & 31 \\
$36-40$ & 9 & 31 \\
$>40$ & 7 & 24,1 \\
Total & 29 & 100 \\
\hline Pendidikan Terakhir & & \\
SMP & 1 & 3,4 \\
SMA & 9 & 31 \\
Diploma & 4 & 13,8 \\
Sarjana & 15 & 51,7 \\
Pasca Sarjana & 0 & 0 \\
Total & 29 & 100 \\
\hline Total Pendapatan per Bulan (juta Rp) & & \\
$1-3$ & 3 & 10,3 \\
$3-5$ & 18 & 62,1 \\
$5-10$ & 5 & 17,2 \\
$>10$ & 3 & 10,3 \\
Total & 0 & 0 \\
& 29 & 100 \\
\hline
\end{tabular}


Sebagian besar peserta yang mengikuti kegiatan pengabdian ini maupun anggota keluarganya, termasuk anak-anak, mengkonsumsi vitamin dalam satu bulan terakhir (Gambar 1.) berupa vitamin $C$ atau multivitamin (Gambar 2.) untuk menjaga stamina (Gambar 3.). Sebagian besar peserta mengetahui berbagai macam vitamin dan kegunaannya bagi tubuh, namun hampir semua belum memiliki pengetahuan mengenai batas dan jumlah penggunaan suplemen vitamin (Tabel 2).

Respon perilaku peserta kegiatan pengabdian (atau anggota keluarganya) dalam penggunaan suplemen vitamin digambarkan dengan diagram pada Gambar 1., Gambar 2., dan Gambar 3. berikut. Perilaku peserta (atau anggota keluarganya) tersebut diketahui dari respon atas pertanyaan tentang; (a) durasi penggunaan sebulan terakhir; (b) jenis vitamin yang dikonsumsi; dan (c) tujuan mengkonsumsi vitamin.

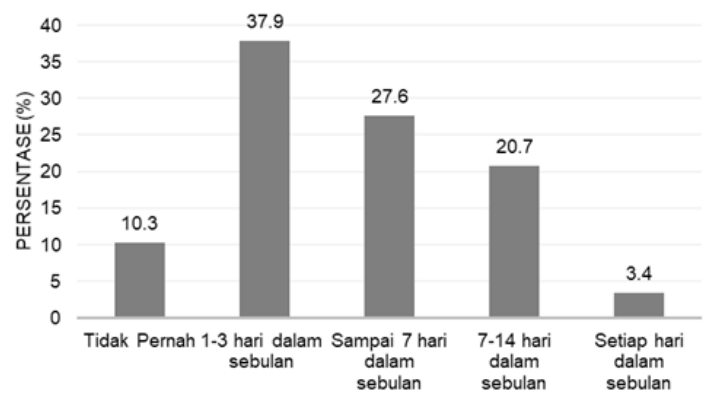

Gambar 1. Diagram jangka waktu konsumsi vitamin dalam satu bulan terakhir

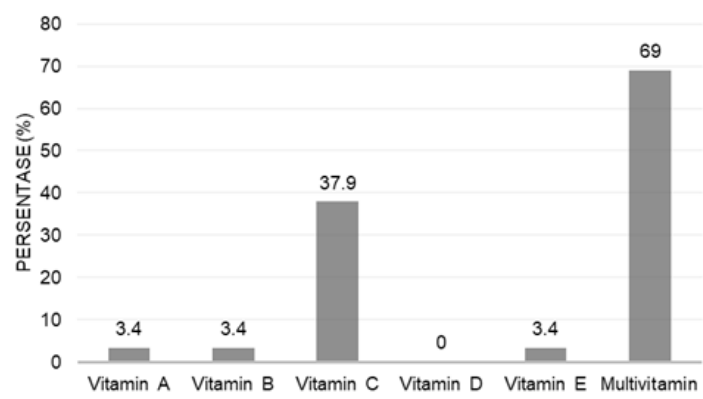

Gambar 2. Diagram jenis vitamin yang dikonsumsi

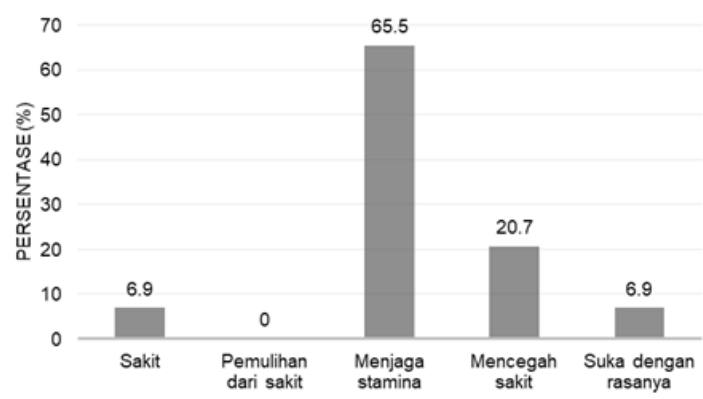

Gambar 3. Diagram tujuan mengkonsumsi vitamin 


\section{Peningkatan Pengetahuan Peserta dalam Penggunaan Vitamin yang Tepat}

Upaya peningkatan pengetahuan peserta mengenai penggunaan vitamin yang tepat menggunakan metode daring memanfaatkan media audio visual berupa video animasi, leaflet dan materi presentasi terbukti berhasil. Persentase dari jawaban benar mengenai pertanyaanpertanyaan yang disampaikan pada post-test menunjukkan peningkatan dibandingkan jawaban pre-test (selengkapnya lihat pada Tabel 2.).

Tabel 2. Persentase jawaban benar dari pertanyaan mengenai penggunaan vitamin yang aman dan benar pada pre-test dan post-test

\begin{tabular}{lcc}
\hline \multicolumn{1}{c}{ Pertanyaan } & Persentase jawaban benar \\
& Pre-test & Post-test \\
\hline Apakah tujuan penggunaan suplemen kesehatan? & 93,1 & 95 \\
Vitamin yang dihasilkan tubuh ketika kulit terkena sinar matahari & 69 & 90 \\
adalah & & 70 \\
Berapa jumlah Vitamin E yang disarankan untuk dikonsumsi orang & 44,8 & 60 \\
dewasa setiap hari? & 37,9 & 80 \\
Vitamin yang dikenal sebagai antioksidan adalah & 27,6 & \\
Berapa batas penggunaan vitamin C dalam sehari? & P. & \\
\hline
\end{tabular}

Terkait evaluasi terhadap pelaksanaan kegiatan pengabdian, peserta memberikan penilaian yang positif. Hasil evaluasi menunjukan minimal $90 \%$ peserta menyatakan setuju dan sangat setuju bahwa isi materi mudah dipahami, media penyampaian menarik dan bermanfaat membantu memahami isi materi serta kegiatan pengabdian dapat menambah pengetahuan mengenai penggunaan suplemen vitamin yang tepat. Ketidaksetujuan terbesar $(10 \%)$ ditunjukkan terhadap aspek waktu kegiatan yang kurang tepat. Hal ini dapat dipahami karena pelaksanaan hari kedua jatuh pada hari Minggu pagi dimana sebagian peserta biasanya melakukan kegiatan olahraga atau lainnya.

Kegiatan ini memperoleh respon yang positif dapat pula dikarenakan adanya beberapa stimulan yang disediakan bagi peserta. Stimulan tersebut berupa penggantian kuota internet bagi peserta yang mengikuti kegiatan dari awal hingga akhir dan hadiah berupa paket suplemen vitamin kepada tiga peserta terbaik. Stimulan tersebut mampu menarik keterikatan para peserta pada kegiatan ini. Meskipun kegiatan dilaksanakan secara daring, namun seluruh peserta mampu berpartisipasi aktif pada semua tahap kegiatan pengabdian ini.

\section{KESIMPULAN}

Pelaksanaan kegiatan pengabdian ini dapat meningkatkan pengetahuan guru dan orangtua siswa TK Aisyiyah Ledug Kecamatan Kembaran Kabupaten Banyumas mengenai penggunaan vitamin yang tepat. Guru dan orangtua siswa TK Aisyiyah Ledug mengetahui tujuan mengkonsumsi vitamin, khasiat dan dosis vitamin $A, C, D$, dan $E$ yang tepat. Peningkatan pengetahuan tersebut merupakan hasil dari metode 
penyampaian materi secara daring menggunakan beragam media audio visual yang menarik.

Peningkatan pengetahuan tentang penggunaan vitamin yang tepat dari guru dan orangtua siswa TK Aisyiyah Ledug bermanfaat untuk mengurangi penyalahgunaan suplemen vitamin pada guru dan orangtua siswa TK Aisyiyah Ledug. Kegiatan serupa dapat dilakukan dengan metode yang sama (daring dan memanfaatkan media audio visual) bagi khalayak yang lebih luas. Jangkauan program yang luas tentunya akan memperluas manfaat kegiatan berupa pengurangan penyalahgunaan suplemen vitamin bagi semua kalangan, tidak terbatas pada guru dan orangtua siswa saja.

\section{UCAPAN TERIMA KASIH}

Penulis menyampaikan terima kasih kepada Lembaga Penelitian dan Pengabdian kepada Masyarakat Pengabdian Masyarakat (LPPM) Universitas Muhammadiyah Purwokerto atas dana hibah untuk pelaksanaan kegiatan Ipteks bagi Masyarakat tahun 2020 ini.

\section{DAFTAR RUJUKAN}

Amanah, I. R., Judistiani, R. T. D., \& Rohmawaty, E. (2019). Studi Farmakoepidemiologi Vitamin Penambah Darah pada lbu Hamil di Kecamatan Jatinangor. Jurnal Kesehatan Vokasional, 4(3), 153-160. https://doi.org/10.22146/jkesvo.44420

Amani, A. R. (2019). Investigation of Supplement (Multivitamin plus to Mineral) Usage at Athletes and Non-Athletes Students. International Journal of Applied Exercise Physiology, 8(1), 180-185. https://doi.org/10.30472/ijaep.v8i1.374

Evans, M. W., Ndetan, H., Perko, M., Williams, R., \& Walker, C. (2012). Dietary supplement use by children and adolescents in the United States to enhance sport performance: results of the National Health Interview Survey. The Journal of Primary Prevention, 33(1), 3-12. https://doi.org/10.1007/s10935-012-0261-4

Fauziah, F. (2018). Pasar suplemen vitamin dan diet berpeluang tumbuh di 2018. Alinea.ld. https://www.alinea.id/bisnis/pasar-suplemen-vitamindan-diet-berpeluang-tumbuh-di-2018-b1Uuk90v

Herriman, M., Fletcher, L., Tchaconas, A., Adesman, A., \& Milanaik, R. (2017). Dietary supplements and young teens: Misinformation and access provided by retailers. Pediatrics, 139(2), 1-9. https://doi.org/10.1542/peds.2016-1257

Jovic, T. H., Ali, S. R., Ibrahim, N., Jessop, Z. M., Tarassoli, S. P., Dobbs, T. D., Holford, P., Thornton, C. A., \& Whitaker, I. S. (2020). Could Vitamins Help in the Fight Against COVID-19? Nutrients, 12(9), 25-50. https://doi.org/10.3390/nu12092550

Kamangar, F., \& Emadi, A. (2012). Vitamin and Mineral Supplements: Do We Really Need Them? International Journal of Preventive Medicine, 3(3), 221-226. https://www.ncbi.nlm.nih.gov/pmc/articles/PMC3309636/

Madjri, A., Fajar, I., \& Francisca H, R. (2011). Studi Kasus: Efek Suplemen 
Vitamin A dan C pada Perilaku Anak Autism Spectrum Disorder. Jurnal Kedokteran Brawijaya, 26(4), 240-245. https://doi.org/10.21776/ub.jkb.2011.026.04.11

Nizar, M. A. (2015). Kelas Menengah (Middle Class) dan Implikasinya bagi Perekonomian Indonesia [Middle Class and Its Implications for the Indonesian Economy]. In IDEAS. Munich Personal RePEc Archive. https://mpra.ub.uni-muenchen.de/98471/

Piekara, A., Krzywonos, M., \& Kaczmarczyk, M. (2020). What do polish parents and caregivers think of dietary supplements for children aged 3-12? Nutrients, 12(10), 1-20. https://doi.org/10.3390/nu12103076

Triana, V. (2006). Macam-Macam Vitamin Dan Fungsinya Dalam Tubuh Manusia. Jurnal Kesehatan Mayarakat, 1(1), 40-47. https://doi.org/10.24893/jkma.v1i1.9

Zhang, F. F., Barr, S. I., McNulty, H., Li, D., \& Blumberg, J. B. (2020). Health effects of vitamin and mineral supplements. The BMJ, 369, m2511. https://doi.org/10.1136/bmj.m2511 